\title{
Semi-preparative purification and validation of monoclonal antibodies for immunotherapy in mice
}

\author{
Huub F.J. Savelkoul *, Ann C.T.M. Vossen, Elvera G. Breedland, G. John M. Tibbe \\ Department of Immunology, Erasmus University, P.O. Box 1738, 3000 DR Rotterdam, Netherlands
}

(Received 22 November 1993; revised received 19 January 1994; accepted 7 February 1994)

\begin{abstract}
A number of rat hybridomas were adapted to grow in RPMI containing either 5\% IgG-depleted FCS or $1 \%$ serum-free Nutridoma. Alternatively, protein-free Ultradoma PF was used. Growth in these media allowed purification procedures to be used that are based on tangential ultrafiltration in combination with affinity chromatography on gels linked to protein $G$ or anti-rat L chain coupled antibodies. The isolated antibody preparations were found to be pure and to consist of monomeric intact IgG. The yield and recovery of mAb using this procedure were found to be consistently high. These antibody preparations were analyzed for endotoxin contamination. Whereas during isolation endotoxin contamination increased, the endotoxin content per mg purified protein did not. Affinity chromatography on Detoxi-gel resulted in the efficient removal of this contamination and using this protocol the antibody preparations obtained were found to be of sufficient purity, activity and low endotoxin content to permit their in vivo use in animal models of immunotherapy
\end{abstract}

Key words: Cytokine; Life cell culture; Minitan concentration; Chromatography, affinity; Endotoxin

\section{Introduction}

Immunological studies require purified, functional antibodies. Because of their specificity especially monoclonal antibodies (mAbs) can serve as crucial reagents for sensitive assays. Moreover, studies involving neutralization of biological activ-

\footnotetext{
* Corresponding author. Fax: 31-10-436 7601. Abbreviations: mAb, monoclonal antibody; FCS, fetal calf serum; SEC, size exclusion chromatography.
}

ities in vivo are dependent on large amounts of specific and active antibody preparations. Therefore, there is a constant need for procedures that enable fast, reliable and easy procedures for purifying mAbs from supernatants of hybridoma cultures. These purification procedures should result in biologically active antibody on a semi-preparative scale. In our studies of the in vivo neutralization of cytokines we need mAb in $100 \mathrm{mg}$ quantities, that are electrophoretically pure and retain their capacity to neutralize cytokine activities in vivo. 
Numerous methods exist for the purification of $\mathrm{mAb}$ from culture supernatants on an analytical and semi-preparative scale (Goding, 1986; Jiskoot et al., 1991a,b). These procedures generally require multiple purification steps and the choice of technique is dependent on the choice of source material, type of immunoglobulin, the degree of purity required, the application, etc. (Savelkoul and Van der Linde-Preesman, 1987; Coppola et al., 1989). Routinely, hybridomas are cultured in tissue culture flasks resulting in large volumes of diluted antibody. Because of the obligatory use of fetal calf serum to allow maximal growth of hybridoma cells, albumin $(2-10 \mathrm{mg} / \mathrm{ml}$, Jiskoot et al., 1991b) and bovine IgG (50-150 $\mu \mathrm{g} / \mathrm{ml}$, Darby et al., 1993) are the major contaminants in hybridoma culture supernatants. Albumin compromises purification procedures by binding tightly to hybridoma IgG, while bovine IgG will copurify together with hybridoma IgG thereby compromising the potential use of protein $A$ or protein $G$ columns (Åkerström et al., 1985; Darby et al., 1993). To avoid the latter problem, expensive specific affinity columns have to be prepared. Since the use of ascitic fluids as a source of mAbs is now discouraged it is likely that culture supernatants will increasingly be used as an alternative source despite the lower concentrations of mAb. Methods of increasing mAb concentrations, e.g., roller bottles, hollow fiber systems, etc. have been used (Altschuler et al., 1986), but they all require a large financial investment and are cost effective only when used to produce gram amounts of mAb. The development of culture Lifecells (Kolanko and Symbol, 1987) achieves low production costs with higher concentrations of $\mathrm{mAb}$. Moreover, new media especially designed for culturing hybridomas have been developed, culminating in the development of serum-free and even proteinfree formulations (Chang et al., 1980; Cleveland et al., 1983; Hoover and Martin, 1990). The use of such media circumvents the need for extensive purification procedures and can effectively speed up the processing time.

A disadvantage of using multiple purification steps is the increased risk of introducing endotoxin contamination (Friberger, 1985). The main sources of such contamination are the water used to make up the buffers, pipetting procedures and columns used to chromatographically purify the antibodies (Schindler and Dinarello, 1989). Those $\mathrm{mAb}$ preparations intended for in vivo neutralization of cytokine activities can not be used when containing such a contamination (Majde, 1992). With the development of new endotoxin inhibitors new column matrices have become available that are able to reduce the endotoxin contamination considerably (Morrison and Curry, 1979; Clauss et al., 1990; Warren et al., 1992).

In this study we describe the development of a quick, reliable and cost-effective way of culturing, purifying and testing $\mathrm{mAb}$ preparations from hybridoma culture supernatants. The results show that this procedure yields pure, biologically active $\mathrm{mAb}$, with a low degree of endotoxin contamination. These mAb preparations have been shown to be effective and useful for in vivo studies.

\section{Materials and methods}

\subsection{Cell lines}

The following rat anti-mouse hybridomas were used: anti-IL-4 (11B11 rat IgG1 (Ohara and Paul, 1985)), anti-IFN- $\gamma$ (XMG 1.2 rat IgG1 (Cherwinski et al., 1987)) and anti-CD3 (17A2 rat IgG2b (Miescher et al., 1989)).

All cell lines were non-adherent and were cultured in Falcon tissue culture flasks (Becton Dickinson, Plymouth, England) in RPMI 1640 medium supplemented with L-glutamine ( $4 \mathrm{mM}$ ), pyruvate $(0.1 \mathrm{M})$, penicillin $(100 \mathrm{IU} / \mathrm{ml})$, streptomycin $(50 \mu \mathrm{g} / \mathrm{ml}), \beta$-mercaptoethanol $\left(5 \times 10^{-5}\right.$ M). To this complete RPMI medium was added either 5\% fetal calf serum (FCS, High Clone, Gibco BRL, Paisley, Scotland), IgG low FCS (containing $\leq 10 \mu \mathrm{g} / \mathrm{ml}$ IgG, HyClone, Logan, UT, USA) or $1 \%(\mathrm{v} / \mathrm{v})$ serum-free Nutridoma-SP (Boehringer, Mannheim, FRG). Alternatively, Ultradoma PF protein-free medium (BioWhittaker, Walkersville, MD, USA) was used as indicated in the Results section. Nutridoma, with a protein concentration less than $40 \mu \mathrm{g} / \mathrm{ml}$ for $1 \%$ working solutions (Hoover and Martin, 1990) and 
Ultradoma, containing no protein have been shown to support higher antibody production than conventional FCS containing media (BioWhittaker catalog, 1993).

\subsection{Hybridoma bulk cultures}

Approximately $1.5 \times 10^{8}$ cells (viability $>90 \%$ as determined by Trypan Blue exclusion) were cultured in Falcon tissue culture flasks $\left(175 \mathrm{~cm}^{2}\right)$ and transferred by a Curapharm infusion set (Medica Hospital Supplies, Den Bosch, Netherlands) to a $3000 \mathrm{ml}$ Fenwal Lifecell tissue culture flask (Baxter, Fenwal Division, Round Lake, IL, USA), in a final concentration of $5 \times 10^{4}$ cells $/ \mathrm{ml}$ (total volume $1500 \mathrm{ml}$ ) as described above. The flask was made of polyolefin plastic and designed to be highly gas permeable. Absence of mycoplasma contamination was verified periodically in all cultures using the MycoTect kit (Gibco).

After culturing for periods of up to 10 days at $37^{\circ} \mathrm{C}$ in $5 \% \mathrm{CO}_{2}$, culture supernatants were harvested by centrifugation for $10 \mathrm{~min}$ at $1500 \mathrm{rpm}$ and kept at $-20^{\circ} \mathrm{C}$ until further purification. Under these conditions no change of culture medium was found to be necessary.

For comparison Falcon tissue culture flaks (175 $\mathrm{cm}^{2}$ ) were used under similar conditions. The cells were washed and resuspended in fresh medium every 3-4 days.

\subsection{Purification of $m A b$}

Supernatants were concentrated using the Minitan Ultrafiltration System (Millipore, Bedford, MA, USA) using four polysulfone membranes (PTHK OMT 05, cut-off at $100 \mathrm{kDa}$ ) operating at a back pressure of 5 psi with a retentate rate of $800 \mathrm{ml} / \mathrm{min}$. The supernatants (routinely $3000 \mathrm{ml}$ ) were concentrated up to ten times the initial volume within $2.5 \mathrm{~h}$.

The mAb from supernatants of hybridoma cultures that did not grow in Ultradoma were purified by affinity chromatography. The $\mathrm{mAb}$ were purified using a $15 \mathrm{ml}$ bed volume protein $G$ column (Immunopure, Pierce, Rockford, IL, USA) equilibrated in binding buffer $(50 \mathrm{mM}$ sodium acetate buffer, pH 5.0). The supernatant was applied to the column at a constant flow rate of $1.5 \mathrm{ml} / \mathrm{min}$ and the $\mathrm{OD}_{280}$ signal was monitored continuously with a UV-1 monitor equipped with a $1 \mathrm{ml}$ flow cell (Pharmacia, Uppsala, Sweden). Bound IgG was eluted using $0.1 \mathrm{M}$ glycine$\mathrm{HCl}$ buffer $(\mathrm{pH} \mathrm{2.5)}$ and immediately neutralized with a few drops of $1 \mathrm{M}$ Tris $(\mathrm{pH}$ 11.2). The column was regenerated by washing with 5 vols. of binding buffer and stored at $4^{\circ} \mathrm{C}$ in $0.2 \%$ sodium azide. Alternatively, a $5 \mathrm{ml}$ bed volume affinity column of mouse anti-rat $(\kappa) \mathrm{L}$ chain coupled to cyanogen bromide activated Sepharose (Pharmacia) was prepared according to the manufacturer's instructions. The column was coupled with $44 \mathrm{mg}$ of purified mAb RG7 7.6 (Springer et al., 1982) and was found to have a binding capacity of $4 \mathrm{mg}$ rat $\mathrm{Ig}$. The running and elution conditions used were identical to the ones used for the protein $\mathrm{G}$ column. The purified material was subsequently dialysed overnight at $4^{\circ} \mathrm{C}$ against PBS.

The purity of isolated mAbs was confirmed by SDS-polyacrylamide gel electrophoresis run under reducing conditions on $12.5 \%$ homogeneous gels using Phastsystem (Pharmacia). Gels were silver stained according to the manufacturers' instructions. Alternatively, the presence of monomeric undamaged IgG was confirmed by size exclusion chromatography (SEC) using a Superdex 200 HR10/30 column and the FPLC system (Pharmacia). The column $\left(V_{\mathrm{o}}=7.8 \mathrm{ml}, V_{\mathrm{t}}=\right.$ $20.7 \mathrm{ml}$ ) was connected to a standard FPLC system consisting of a LCC liquid chromatography controller, two P-500 pumps, a MV-7 injector equipped with a $200 \mu \mathrm{l}$ sample loop, a UV-1 monitor at $280 \mathrm{~nm}$ and 0.1 AUFS (absorption units full scale) sensitivity and a FRAC-100 fraction collector. Isocratic elution at a flow rate of 1 $\mathrm{ml} / \mathrm{min}$ at room temperature $\left(23 \pm 2^{\circ} \mathrm{C}\right)$ was performed with $10 \mathrm{mM}$ phosphate-buffered saline containing $150 \mathrm{mM} \mathrm{NaCl}$ (PBS), pH 7.3. The molecular mass of the eluted peaks $\left(V_{\mathrm{e}}\right)$ was calculated from $K_{\mathrm{Av}}=\left(V_{\mathrm{e}}-V_{\mathrm{o}}\right) /\left(V_{\mathrm{t}}-V_{\mathrm{o}}\right)$ and the selectivity curve $K_{\mathrm{Av}}=2.31-0.38 \log M_{\mathrm{r}}$.

For long-time storage at $-70^{\circ} \mathrm{C}$, purified $\mathrm{IgG}$ was concentrated to at least $1 \mathrm{mg} / \mathrm{ml}$ in PBS through an Amicon YM10 filter (Amicon, Danvers, MA, USA). The protein concentration was 
determined spectrofotometrically using an $\mathrm{OD}_{280 \mathrm{~nm}}$ extinction coefficient of 1.36 at 1 $\mathrm{mg} / \mathrm{ml}$.

\subsection{Rat IgGI ELISA}

Microtiter plates were coated with $4 \mu \mathrm{g} / \mathrm{ml}$ of a purified rat IgG1-specific mouse mAb Mr G1P (clone MRG 1; Pharmingen, San Diego, CA, USA). Appropriate dilutions of the samples in PBS were incubated for $3 \mathrm{~h}$ at room temperature. Subsequently, $0.5 \mu \mathrm{g} / \mathrm{ml}$ of a biotin-conjugated mouse anti-rat IgL ( $\kappa$ chain) mAb (clone MRK 1; Pharmingen), and $1 \mu \mathrm{g} / \mathrm{ml}$ of a streptavidinlabelled horseradish peroxidase (Jackson Immunological Laboratory, Wetsgrove, PA, USA) were used. The substrate 2,2'-azino-di-[3-ethylbenzthiazoline] (ABTS; Sigma, St. Louis, MO, USA) in a 1:1 mixture of $0.2 \mathrm{M} \mathrm{Na}_{2} \mathrm{HPO}_{4}$ and $0.1 \mathrm{M}$ citric acid (activated with $\mathrm{H}_{2} \mathrm{O}_{2}$ ) was used for color development. The reaction was stopped with $0.2 \mathrm{M}$ citric acid. A purified rat IgG1 (clone R3 34; Pharmingen) was used as an isotype-specific standard. This ELISA has a detection limit of $1.25 \mathrm{ng} / \mathrm{ml}$ of rat $\mathrm{IgG} 1$.

\subsection{Endotoxin contamination}

The concentration of contaminating endotoxin was determined using the Limulus amebocyte lysate (LAL) micromethod as described previously (Kreeftenberg et al., 1977; Friberger, 1985). Briefly, $20 \mu$ l of LAL (sensitivity: $0.125 \mathrm{EU} / \mathrm{ml}=$ $0.0125 \mathrm{ng} / \mathrm{ml}$; Pyrotell Cape Cod, Woodshole, MA, USA) was incubated in flat-bottomed microtiter plates (Greiner, Alphen a/d Rijn, Netherlands) together with $20 \mu \mathrm{l}$ of sample for $60 \mathrm{~min}$ at $37^{\circ} \mathrm{C}$. The samples were tested at various dilutions prepared in pyrogen-free water (Lansberg, Uden, Netherlands). As a reference a dilution curve starting at $2 \mathrm{EU} / \mathrm{ml}$ of $E$. coli standard endotoxin (Sanbio, Uden, Netherlands) was used. After incubation, gel formation indicating an endotoxin concentration of $\geq 0.125 \mathrm{EU} / \mathrm{ml}$ was visualised by adding $10 \mu 10.1 \%(\mathrm{w} / \mathrm{v})$ chlorophenol red (Merck, Darmstadt, Germany) and placing the plate in a vertical position. At a dose of $0.125 \mathrm{U} / \mathrm{ml}$ or less, no gel formation occurred.
The endotoxin concentration was calculated by multiplying the dilution factor of the last positive endpoints by the LAL sensitivity.

Endotoxin contamination was removed from the antibody preparations by affinity chromatography on a $2 \mathrm{ml}$ bed volume Detoxi-gel column (Pierce) using PBS as running buffer. To ensure maximum binding efficiency the use of neutral buffers (PBS, pH 7.3) containing $150 \mathrm{mM} \mathrm{NaCl}$ was essential. The column had a binding capacity of $2 \mathrm{mg}$ endotoxin $/ \mathrm{ml}$ gel and was eluted with PBS containing $1 \%(\mathrm{w} / \mathrm{v})$ sodium deoxycholate (Sigma). After use the column was stored in pyrogen-free water with $0.2 \%$ sodium azide.

\section{Results}

\subsection{Optimal culture conditions for $m A b$ production by hybridoma cells in Lifecells}

Before using Lifecells, the medium requirements of the various hybridomas were determined. To this end, tissue culture flasks $\left(75 \mathrm{~cm}^{2}\right.$ seeded with $15 \mathrm{ml}$ containing $5 \times 10^{4}$ cells $/ \mathrm{ml}$ ) were seeded with $11 \mathrm{~B} 11$ or $17 \mathrm{~A} 2$ cells, adapted over five splittings to growth in RPMI containing $5 \%$ normal FCS or 5\% IgG-depleted FCS or in Ultradoma medium free of protein. After several days of culture the rat Ig produced in the supernatant was assayed with a specific ELISA.

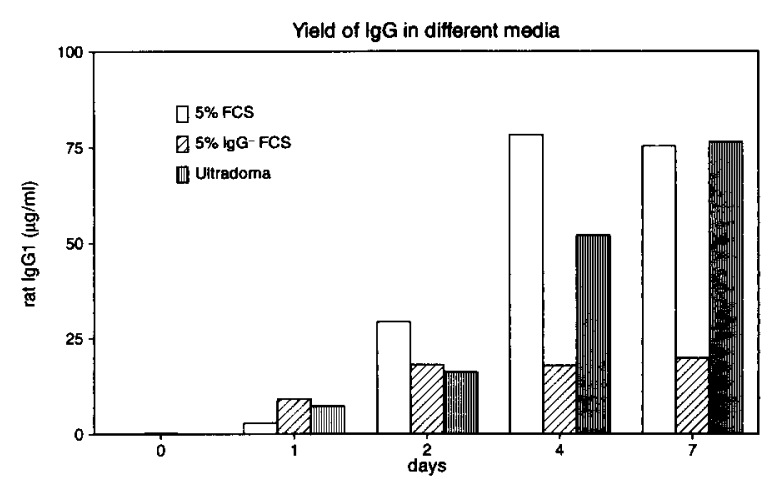

Fig. 1. Cultures of $11 \mathrm{~B} 11$ cells (at $5 \times 10^{4} / \mathrm{ml}$ in $15 \mathrm{ml}$ ) adapted to Ultradoma or RPMI medium containing either $5 \%$ FCS or 5\% IgG-depleted FCS were grown in $75 \mathrm{~cm}^{2}$ culture flasks. Rat IgG1 levels $(\mu \mathrm{g} / \mathrm{ml})$ were determined by ELISA. 
The results of the 11B11 cultures showed that after 7 days of culture the supernatants of cells grown in Ultradoma had accumulated similar amounts of $\mathrm{mAb}$ to those grown in normal FCS (Fig. 1). Another rat IgG1, XMG 1.2, could equally well be adapted to grow in Ultradoma (data not shown). The only difference was that cultures grown in Ultradoma grew more slowly than those in normal FCS. The cells cultured in IgG-depleted FCS consistently produced less $\mathrm{mAb}$ than those grown in the other media. Surprisingly, the rat IgG2b secreting $17 \mathrm{~A} 2$ hybridoma cells did not survive in the Ultradoma medium, athough they were adapted to the medium. We have tested three different rat IgG2a-and IgG2b-secreting hybridomas and none could be adapted to growth in Ultradoma medium (data not shown). On the other hand, these rat hybridomas could easily be adapted to grow in RPMI containing IgG-depleted FCS.

Lifecells were used according to the manufacturer's instructions: a 3 liter cell was filled with $1500 \mathrm{ml}$ of medium containing cells at a seeding density of $5 \times 10^{4}$ per ml. Lifecells as well as 175 $\mathrm{cm}^{2}$ tissue culture flasks containing $25 \mathrm{ml}$ of medium were seeded with $11 \mathrm{~B} 11$ cells in Ultradoma or RPMI containing $1 \%(\mathrm{v} / \mathrm{v})$ Nutridoma. At various times viability was determined (Table

Table 1

Viability of hybridoma cells cultured in Lifecells and flasks

\begin{tabular}{|c|c|c|c|c|c|c|}
\hline \multirow{3}{*}{$\begin{array}{l}\text { Days of } \\
\text { culture }\end{array}$} & \multirow{2}{*}{\multicolumn{2}{|c|}{$\begin{array}{l}\text { Nutridoma } \\
\text { Culture flask }\end{array}$}} & \multicolumn{4}{|c|}{ Ultradoma } \\
\hline & & & \multicolumn{2}{|c|}{ Culture flasks } & \multicolumn{2}{|l|}{ Lifecells } \\
\hline & $\begin{array}{l}\text { Cells } \times \\
10^{4} / \mathrm{ml}\end{array}$ & $\%$ & $\begin{array}{l}\text { Cells } \times \\
10^{4} / \mathrm{ml}\end{array}$ & $\%$ & $\begin{array}{l}\text { Cells } \times \\
10^{4} / \mathrm{ml}\end{array}$ & $\%$ \\
\hline 0 & 5 & 90 & 5 & 95 & 5 & 85 \\
\hline 1 & 8 & 90 & 6 & 95 & nd & nd \\
\hline 2 & 15 & 80 & 16 & 80 & 6 & 90 \\
\hline 3 & 18 & 70 & 43 & 60 & nd & nd \\
\hline 4 & 15 & 56 & 19 & 40 & 9 & 90 \\
\hline 6 & nd $^{\text {a }}$ & nd & nd & nd & 29 & 75 \\
\hline 7 & nd & nd & nd & nd & 45 & 60 \\
\hline 10 & nd & nd & nd & nd & 51 & 25 \\
\hline
\end{tabular}

$11 \mathrm{~B} 11$ cells were cultured in Nutridoma or Ultradoma medium. Viability was assessed using the Trypan blue exclusion test in a hemocytometer. Cultures were performed either in flasks (and followed for 4 days) or in Lifecells (and followed for 9 days).

${ }^{\text {a }}$ Not done.

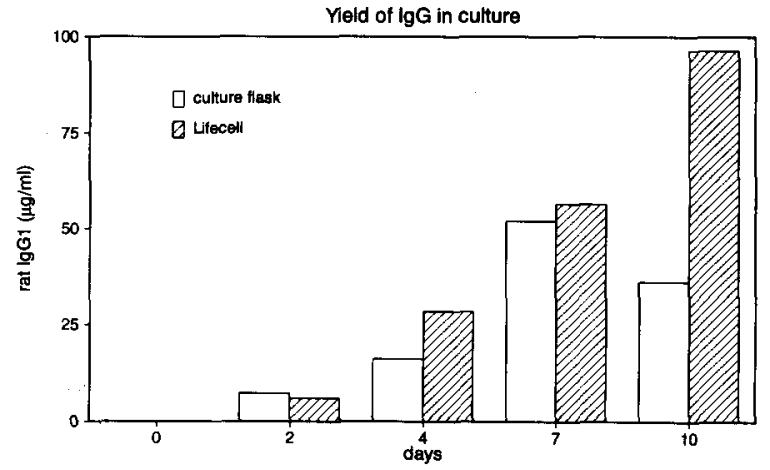

Fig. 2. Cultures of $11 \mathrm{~B} 11$ cells adapted to Ultradoma were grown in culture flasks $\left(125 \mathrm{~cm}^{2}\right.$ with $25 \mathrm{ml}$ of $5 \times 10^{4}$ cells $\left./ \mathrm{ml}\right)$ or in Lifecells ( $1500 \mathrm{ml}$ with $5 \times 10^{4}$ cells $\left./ \mathrm{ml}\right)$. Rat IgG1 levels $(\mu \mathrm{g} / \mathrm{ml})$ were determined in ELISA.

1) and rat IgG1 concentrations in the Ultradoma containing cultures were determined using a specific ELISA (Fig. 2). The results show that although the viability of the cultures in Lifecells had dropped considerably by day 10 , the accumulated $\mathrm{mAb}$ level was high $(96 \mu \mathrm{g} / \mathrm{ml})$. It was found that when the hybridoma cells were adapted to grow in Ultradoma PF or RPMI supplemented with Nutridoma, both media were equally effective in sustaining cellular proliferation and viability (Table 1 ). The cultures in the conventional culture flasks had to be split after 4 days of culture after which the data for viability and $\mathrm{mAb}$ production became irrelevant. By comparing the results in the conventional flasks and those of Lifecells it became apparent that production levels were approximately the same. Nevertheless, since Lifecell cultures can stay productive for up to 10 days without the need for splitting many culture flasks would be needed to equal the production of one Lifecell. Accordingly, Lifecells were considered to be superior.

\subsection{Purification of $m A b$ from Lifecell culture su- pernatants}

The purification procedure that we employed in this study was based on concentrating the culture supernatants in a Minitan tangential filtration system using a $10^{5} \mathrm{kDa}$ cut-off membrane. This membrane ensured rapid concentra- 
tion with good retention of immunoglobulins and little albumin contamination. Subsequently, the Ig was further purified by affinity chromatography (when the Ultradoma medium could not be used) either on protein $G$ or anti- $\kappa$ L chain immobilized Sepharose. Finally, the Ig was concentrated by Amicon ultrafiltration. Purity was checked by SDS-PAGE analysis, while size exclusion chromatography permitted analysis of the degree of monomeric IgG and confirmed the molecular weight (Savelkoul and Breedland, unpublished observations).

Depending on the ability of hybridomas to adapt to growth in Ultradoma or RPMI containing IgG-depleted FCS, the purification procedure employed contained no affinity chromatography step or was dependent on the use of protein $G$ only. The use of this matrix was imperative since rat IgG1 antibodies bind in appreciable amounts to protein G. In order to bind antibodies to protein $\mathrm{G}$ columns without loss of binding activity, several binding buffers were tested for the recovery of functional IgG. To this end, rat IgG1 antibodies present in $20 \mathrm{ml}$ crude culture supernatants diluted $1 / 2$ in various binding buffers were allowed to bind to a $1 \mathrm{ml}$ protein $\mathrm{G}$ test column. All columns were eluted with $0.1 \mathrm{M}$ glycine- $\mathrm{HCl}, \mathrm{pH} 2.5$ (Table 2). From this study it became apparent that using $50 \mathrm{mM}$ acetate yielded the highest levels of IgG with good functional activity in the ELISA procedure.

Table 2

Optimal buffer combination for protein $\mathrm{G}$ affinity chromatography

\begin{tabular}{llll}
\hline Buffer combination & $\mathrm{pH}$ & $\begin{array}{l}\text { Eluate } \\
\left(\% \mathrm{OD}_{280}\right)\end{array}$ & $\begin{array}{l}\text { Recovery } \\
\text { IgG }(\% \text { in } \\
\text { eluate })\end{array}$ \\
\hline $50 \mathrm{mM}$ sodium acetate & 5.0 & 63 & 85 \\
$50 \mathrm{mM}$ acetate $+0.1 \mathrm{M}$ & 5.0 & 47 & 90 \\
EDTA + $3 \mathrm{M} \mathrm{NaCl}$ & & & \\
$0.01 \mathrm{M}$ PBS $(0.15 \mathrm{M} \mathrm{NaCl})$ & 7.2 & 30 & 78 \\
$0.01 \mathrm{M}$ PBS $+3 \mathrm{M} \mathrm{NaCl}$ & 7.2 & 50 & 80 \\
$50 \mathrm{mM}$ Tris-HCl $+0.1 \mathrm{M}$ & 7.8 & 60 & 67 \\
EDTA $+0.15 \mathrm{M} \mathrm{NaCl}$ & & & \\
\hline
\end{tabular}

Recovery is expressed in terms of IgG content as a percentage of the IgG1 level in unseparated culture supernatant. IgG1 levels were determined in an ELISA.
Table 3

Yield and recovery during the various purification steps of rat IgG2b mAb

\begin{tabular}{lcccc}
\hline $\begin{array}{l}\text { Purification } \\
\text { step }\end{array}$ & $\begin{array}{l}\text { Volume } \\
(\mathrm{ml})\end{array}$ & $\begin{array}{l}\text { IgG content } \\
(\mu / \mathrm{ml})\end{array}$ & $\begin{array}{l}\text { Yield } \\
(\mu \mathrm{g})\end{array}$ & $\begin{array}{l}\text { Recovery } \\
(\%)\end{array}$ \\
\hline Supernatant & 3000.0 & 20.3 & 60900 & 100.0 \\
Minitan & 380.0 & 115.3 & 43814 & 71.9 .0 \\
$\begin{array}{l}\text { Anti-L chain } \\
\quad \text { column }\end{array}$ & 62.8 & 649.6 & 40803 & 67.0 \\
Amicon & 11.9 & 3229.9 & 38436 & 63.1
\end{tabular}

Purification and production of IgG from 3 liter culture supernatant of $17 \mathrm{~A} 2$ cells cultured for 10 days in RPMI supplemented with 5\% (IgG depleted) FCS in two Lifecells.

The isolation of rat IgG1 mAb from 11B11 cells, adapted to grow in Ultradoma, consisted mainly of concentrating the culture supernatants in Minitan and Amicon systems. This procedure was found to be sufficient to yield pure IgG1. When the hybridoma could not be adapted to growth in Ultradoma medium, IgG-depleted FCS was used as a serum source. In combination with Minitan ultrafiltration and protein $G$ affinity chromatography (using the above mentioned binding buffer system), the rat IgG could be

Table 4

Influence of protein purification on cumulated endotoxin contamination

\begin{tabular}{|c|c|c|c|c|}
\hline Purification step & $\begin{array}{l}\text { Volume } \\
(\mathrm{ml})\end{array}$ & $\begin{array}{l}\text { IgG1 } \\
\text { content } \\
\text { (mg) }\end{array}$ & $\begin{array}{l}\text { Endo- } \\
\text { toxin } \\
\text { (ng/ } \\
\text { ml) }\end{array}$ & $\begin{array}{l}\text { Contami- } \\
\text { nation } \\
\text { (ng endo- } \\
\text { toxin / } \\
\text { mg Ig) }\end{array}$ \\
\hline \multicolumn{5}{|l|}{ XMG 1.2 (rat IgG1) } \\
\hline Crude supernatant & 650 & 94 & 0.2 & 1.38 \\
\hline Minitan concentration & 160 & 92 & 0.8 & 1.39 \\
\hline Protein G column & 25 & 18 & 1.2 & 1.58 \\
\hline Amicon filtration & 15 & 13 & 1.6 & 1.85 \\
\hline \multicolumn{5}{|l|}{ 17A2 (rat IgG2b) } \\
\hline Crude supernatant & 3000 & 60.9 & 0.4 & 19.7 \\
\hline Minitan concentration & 380 & 43.8 & 0.8 & 6.9 \\
\hline anti-L chain column & 63 & 40.8 & 1.6 & 2.5 \\
\hline Amicon filtration & 12 & 38.4 & 3.2 & 1.0 \\
\hline
\end{tabular}

XMG 1.2 (rat IgG1) and 17A2 (rat IgG2b) hybridoma cells were cultured in RPMI + 5\% (IgG-depleted) FCS for 10 days either in $75 \mathrm{~cm}^{2}$ culture flasks $\left(15 \mathrm{ml}\right.$ with $\left.5 \times 10^{4} / \mathrm{ml}\right)$ or in two Lifecells, respectively. Endotoxin contamination was determined by LAL assay. 
purified in high yield with good recovery of biological activity.

Affinity chromatography on immobilized anti-L chain antibodies was employed for rat IgG2b hybridoma supernatants. Table 3 shows data on rat IgG2b antibodies purified from medium containing 5\% IgG-depleted FCS using affinity chromatography on anti- $\mathrm{L}$ chain-Sepharose. As is clear from these data, the mAb could be purified in high yield and recovery of biological activity. Analysis on SDS-PAGE and size exclusion chromatography on FPLC equipped with a Superdex 200 column revealed a preparation of pure $\left(M_{\mathrm{r}}=\right.$ $160 \mathrm{kDa}, \mathrm{H} \gamma$ chain $=50 \mathrm{kDa}$ ) homogeneous and intact IgG molecules.

\subsection{Endotoxin contamination and removal}

It has been previously observed that endotoxin contamination of antibody preparations can severely compromise studies on the activity of cytokines in vivo. To determine endotoxin contamination levels during routine culturing and purification of mAb, cultures of XMG 1.2 and 17A2 were started in flasks and Lifecells. Subsequently, the Ig was purified using Minitan ultrafiltration, affinity chromatography on either protein $\mathrm{G}$ or anti- $\mathrm{L}$ chain columns and Amicon ultrafiltration. The results (Table 4) show that during the isolation procedure the endotoxin contamination steadily increased. Endotoxin contamination

Table 5

Removal of endotoxin contamination by Detoxi affinity chromatography

\begin{tabular}{llll}
\hline Sample & $\begin{array}{l}\text { Endotoxin } \\
(\mathrm{ng} / \mathrm{ml})\end{array}$ & Detoxi-gel & $\begin{array}{l}\text { Endotoxin } \\
(\mathrm{ng} / \mathrm{ml})\end{array}$ \\
\hline LPS & 10.1 & Effluent & $<0.125$ \\
& & Eluate & 8.6 \\
$17 \mathrm{~A} 2$ & 3.2 & Effluent & $<0.125$ \\
& & Eluate & 2.95 \\
\hline
\end{tabular}

A Detoxi-gel $(2 \mathrm{ml})$ column was used to remove endotoxin contamination (as determined by LAL assay with a detection limit of $0.125 \mathrm{ng} / \mathrm{ml}$ ) from $1 \mathrm{ml}$ of purified $17 \mathrm{~A} 2$ protein preparation $(1 \mathrm{mg} / \mathrm{ml})$. A standard LPS preparation containing $100 \mathrm{EU} / \mathrm{ml}(10 \mathrm{ng} / \mathrm{ml})$ was used as a control. PBS was used as running buffer. was of the order of 1-2 ng per mg of purified Ig. Since in vivo antibody treatment in mice is mostly performed with doses of $0.2-1 \mathrm{mg}$ per mouse, the endotoxin content would vary between $0.2-2 \mathrm{ng}$ (2-20 EU) per mouse.

Preparations of $17 \mathrm{~A} 2 \mathrm{mAb}$ containing $\geq 2 \mathrm{ng}$ endotoxin per mg of purified Ig were subjected to affinity chromatography on a $2 \mathrm{ml}$ bed volume Detoxi-gel in PBS. An LPS standard (containing $100 \mathrm{EU} / \mathrm{ml}$ ) was also chromatographed as a control (Table 5). The results suggest that single-step affinity chromatography could be used to reduce endotoxin contamination in the LPS standard from $100 \mathrm{EU} / \mathrm{ml}$ to $1.25 \mathrm{EU} / \mathrm{ml}$. This corresponds to a removal efficiency of $85 \%$. The endotoxin contamination in purified $\mathrm{mAb}$ preparations was reduced to levels ( $\leq 1 \mathrm{ng}$ ) which would be suitable for in vivo applications.

\section{Discussion}

The in vitro growth and maintenance of cells was initially achieved by supplementing culture media with poorly defined fluids such as bovine serum. The variable composition of serum can cause inconsistencies between hybridoma culture conditions and create difficulties in the purification and quantification of secreted mAb. Different batches of FCS display a large variation (up to four-fold) in their IgG content. Therefore, assessment of the bovine IgG content before using a batch of FCS might be worthwhile. Moreover, the use of FCS carries the risk of introducing contaminants such as viruses and mycoplasma (Samoilovitch et al., 1987). The ability to grow hybridomas readily in standard media suggests that these cells have simple growth requirements, and this has been confirmed by a number of studies (Kawamoto et al., 1986; Kovar and Franek, 1986). Due to differing growth requirements of different cell lines these preparations have not been satisfactory. With the development of $\mathrm{Nu}$ tridoma and Ultradoma new serum-free and even protein-free media have been developed that support antibody production. Serum-free media consist of a complete nutrient formulation (consisting 
of one or more component mixtures) capable of supporting cellular proliferation and/or biological production without serum supplementation or further addition of growth factors. Such formulations may contain purified natural or recombinant growth factors or less well-defined serum fractions or tissue or organ extracts. Serum-free medium cannot contain serum of any kind from any source. Protein-free media consist of a complete nutrient formulation (consiting of one or more component mixtures) capable of supporting cellular proliferation and/or biological production that contains all biochemically defined ingredients and absolutely no polypeptide components. Protein-free media do not contain albumin, insulin, transferrin, fetuin, peptide growth factors, or immunoglobulins. The serum-free Nutridoma medium favors three compounds: transferrin, albumin and insulin. To these compounds sodium selenite and sometimes hormones are added. 1\% of this supplement can replace 10\% FCS in supporting cell growth and mAb production. Small alterations in the medium, and in other growth conditions such as $\mathbf{p H}$ and temperature may stress the cells and make them less stable. Since a key factor in the consistency of mAb production is the stability of the cell line, there is a need for rigorous quality control of the culture media. Furthermore, preliminary studies have shown that the methods described here for rat hybridomas are also applicable to mouse hybridomas. When using either of the serum-free formulas, cell growth appeared to be slower, but antibody production was generally enhanced as observed previously by using different formulations (Tharakan et al., 1986). It has been suggested (Hoover and Martin, 1990) that slower cell growth is beneficial for $\mathrm{mAb}$ production since it sustains longer culture times and permits the use of Lifecells. The Lifecell can be used both as a seed vessel and as a replacement for large $\mathrm{T}$ flasks, spinner flasks and small bioreactors (Kolanko and Symbol, 1987; Samoilovitch et al., 1987).

Culture supernatant for mAb purification contains in addition to the media components, cellular DNA and proteins, endotoxin and protein species such as aggregates, fragments and denatured products (Scott, 1987). The isolation proce- dures for mAbs intended for in vivo usage or as critical assay reagents usually includes SEC as one of the essential steps (either for purification or for desalting the final product (Schachter, 1986; Coppola et al., 1989)). The disadvantages of this approach are the low sample volumes that can be processed (1-2\% of the column volume), the high protein concentration of the sample that is required (1-10 mg/ml), and the use of long columns to minimize dilution but which result in long run times. A high resolution matrix, such as Superdex 200 , in combination with FPLC provides a narrow elution profile for the material of interest. Moreover, run times of up to $1 \mathrm{~h}$ can still lead to sufficient resolution (Savelkoul and Breedland, unpublished observations). Furthermore, the matrix is useful in the structural analysis of the isolated $\mathrm{mAb}$. The removal of endotoxin contamination is most efficiently achieved by specific affinity chromatography on a polymyxin B column. SEC will also help remove antibody-related contaminants such as antibody aggregates and fragments that may have the same surface charge characteristics as the intact mAb (Hanna et al., 1992).

Endotoxins are pyrogenic lipopolysaccharide components of gram-negative bacteria. Since these bacteria are ubiquitous in nature, it is not surprising that endotoxins are frequent contaminants of biochemical preparations. Maintaining a low endotoxin concentration is extremely important if in vivo studies are to be performed. Even at doses of only $\mathrm{ng} / \mathrm{ml}$, they have been shown to exert large biological effects in animals and in cell cultures. Eliminating contamination of macromolecular endotoxins from aqueous solutions is impossible by ultrafiltration when these solutions contain proteins or other macromolecules (Schindler and Dinarello, 1989). Techniques, such as size exclusion chromatography usually introduce as much contamination as they remove. Affinity chromatography, using an immobilized ligand which has a unique specificity for pyrogens is effective in the removal of pyrogens from solution (Clauss et al., 1990; Warren et al., 1992). Alternatively, the polycation polymyxin $B$ is frequently used to neutralize the contaminating endotoxins. The action of polymyxin B depends upon its 
charge neutralization of the electronegative phosphate groups of the lipid A component (Morrison and Curry, 1979).

The LAL assay can be effectively used for direct detection of contaminating endotoxins in many products. Recent observations have indicated that some cytokines, such as tumor necrosis factor $\alpha$, can synergize with contaminating endotoxins at levels not reliably detected by the LAL test (Rothstein and Schreiber, 1988). Therefore, LAL negativity does not guarantee the absence of an endotoxin effect. Immunological studies can be further confounded by other contaminating microbial cell wall products that do not react in the LAL test but do efficiently induce cytokine production, e.g., peptidoglycans and mycoplasmal products (Dinarello and Krueger, 1986).

Monoclonal antibodies are relatively complex proteins and the stability of both the cell culture process and antibody production is important. In this study we have shown that the application of serum-free and protein-free media in combination with cell culturing in Lifecells permits sufficient cell growth and mAb production. Secondly, the use of ultrafiltration and affinity chromatography resulted in high yields of functionally active mAbs.

\section{Acknowledgements}

We thank professor R. Benner for critically reviewing the manuscript, Mr. T. van Os for graphic design and photography and Ms. A.C. de Vries for help in the preparation of the manuscript.

\section{References}

Åkerström, B., Brodin, T., Reis, K. and Björk, L. (1985) Protein G: a powerful tool for binding and detection of monoclonal and polyclonal antibodies. J. Immunol. 135, 2589.

Altschuler, G.L., Dziewulski, D.M., Sowek, J.A. and Belfort, G. (1986) Continuous hybridoma growth and monoclonal antibody production in hollow fiber reactor-separators. Biotechnol. Bioeng. 28, 646.

Chang, T.H., Steplewski, Z. and Koprowski, H. (1980) Pro- duction of monoclonal antibodies in serum-free medium. J. Immunol. Methods 39, 369.

Cherwinski, H.M., Schumacher, J.H., Brown, K.D. and Mosmann, T.R. (1987) Two types of mouse helper $T$ cell clones. III. Further differences in lymphokine synthesis between Th1 and Th 2 clones revealed by RNA hybridization, functionally monospecific bioassays and monoclonal antibodies. J. Exp. Med. 166, 1229.

Clauss, M., Murray, J.C., Vianna, M., De Waal, R., Thurston, G., Nawroth, P., Gerlach, H., Gerlach, M., Bach, R., Familletti, P.C. and Stern, D. (1990) A polypeptide factor produced by fibrosarcoma cells that induces tissue factor and enhances the procoagulant response to tumor necrosis factor/cachectin. J. Biol. Chem. 265, 7078.

Cleveland, W.L., Wood, I. and Erlanger, B.F. (1983) Routine large-scale production of monoclonal antibodies in a protein-free culture medium. J. Immunol. Methods 56, 221.

Coppola, G., Underwood, J., Cartwright, G. and Hearn, M.T.W. (1989) High-performance liquid chromatography of amino acids, peptides and proteins. XCIII. Comparison of methods for the purification of mouse monoclonal immunoglobulin $\mathrm{M}$ autoantibodies. J. Chromatogr. 476, 269.

Darby, C.R., Hamano, K. and Wood, K.J. (1993) Purification of monoclonal antibodies from tissue culture medium depleted of IgG. J. Immunol. Methods 159, 125.

Dinarello, C.A. and Krueger, J.M. (1986) Induction of interleukin- 1 by synthetic and naturally occurring muramyl peptides. Fed. Proc. 45, 2545.

Friberger, P. (1985) The design of a reliable, endotoxin test. In: J.W. Ten Cate, H.R. Büller, A. Sturk and J. Levin (Eds.), Bacterial Endotoxins: Structure, Biomedical Significance and Detection with the Limulus Amebocyte Lysate Test. Alan R. Liss, New York, pp. 139-149.

Goding, J.W. (1986) Monoclonal antibodies. Principles and Practice, 2nd edn. Academic Press, New York.

Hanna, L.S., Pine, P., Reuzinsky, G., Nigam, S. and Omstead, D.R. (1991) Removing specific cell culture contaminants in a MAb purification process. BioPharmacology 4, 33 .

Hoover, C.S. and Martin, R.L. (1990) Antibody production and growth of mouse hybridoma cells in nutridoma media ${ }^{R}$ supplements. BioTechniques 8, 76.

Jiskoot, W., Hoven, A.M.V., De koning, A.A.M., Leerling, M.F., Reubsaet, C.H.K., Crommelin, D.J.A. and Beuvery, E.C. (1991a) Purification and stabilization of a poorly soluble mouse IgG3 monoclonal antibody. J. Immunol. Methods 138, 181.

Jiskoot, W., Van Hertrooij, J.J.C.C., Hoven A.M.V., Klein Gebbink, W.T.M., Van der Velden-de Groot, T., Crommelin, D.J.A. and Beuvery, E.C. (1991b) Preparation of clinical grade monoclonal antibodies from serum-containing cell culture supernatants. J. Immunol. Methods 138, 273.

Kawamoto, T., Sato, J.D., McClure, D.B. and Sato, G.H. (1986) Serum-free medium for the growth of NS-1 mouse myeloma cells and the isolation of NS-1 hybridomas. Methods Enzymol. 121, 266. 
Kolanko, W. and Symbol, R. (1987) Improved yields of monoclonal antibodies in flexible plastic containers. Proceedings of Biotech U.S.A. The 4th Annual Industry Conference and Exhibition. Santa Clara, CA.

Kovár, J. and Franek, F. (1986) Serum-free medium for hybridoma and parental myeloma cell cultivation. Methods Enzymol. 121, 277.

Kreeftenberg, J.G., Loggen, H.G,, Van Ramshorst, J.D. and Beuvery, E.C. (1977) The Limulus amebocyte lysate test: micromethod and application in the control of sera and vaccines. Dev. Biol. Stand. 34, 15.

Majde, J.A. (1992) Endotoxin detection. Immunology Today 13, 329.

Miescher, G.C., Schreyer, M. and MacDonald, H.R. (1989) Production and characterization of a rat monoclonal antibody against the murine CD3 molecular complex. Immunol. Lett. 23, 113.

Morrison, D.C. and Curry, B.J. (1979) The use of polymyxin B and $\mathrm{C} 3 \mathrm{H} / \mathrm{HeJ}$ mouse spleen cells as criteria for endotoxin contamination. J. Immunol. Methods 27, 83.

Ohara, J. and Paul, W.E. (1985) Production of a monoclonal antibody to and molecular characterization of B cell stimulatory factor-1. Nature 315, 333.

Rothstein, J.L. and Schreiber H. (1988) Synergy between tumor necrosis factor and bacterial products causes hemorrhagic necrosis and lethal shock in normal mice. Proc. Natl. Acad. Sci. USA 85, 607.

Samoilovich, S.R., Dugan, C.B. and Macario A.J.L. (1987) Hybridoma technology: new developments of practical interest. J. Immunol. Methods 101, 153.
Savelkoul, H.F.J. and Van der Linden-Preesman, A.A. (1987) Rapid purification of mouse IgE antibodies by multi-column liquid chromatography. In: Proceedings Second RPLC symposium. Pharmacia, Woerden, p. 83.

Schachter, H. (1986) Biosynthetic controls that determine the branching and microheterogeneity of protein-bound oligosaccharides. Biochem. Cell Biol. 64, 163.

Schindler R. and Dinarello, C.A. (1989) A method for removing interleukin-1 and tumor necrosis factor-inducing substances from bacterial cultures by ultrafiltration with polysulfone. J. Immunol. Methods 116, 159.

Scott, R.W. (1987) Purification of monoclonal antibodies from large-scale mammalian cell culture perfusion systems. Biotechnol. Prog. 3, 49.

Springer, T.A., Bhattacharya, A., Try Cardoza, J., SanchezMadrid, F. (1982) Monoclonal antibodies specific for rat IgG1, IgG2a, and IgG2b subclasses, and kappa chair monotypic and allotypic determinants: reagents for use with rat monoclonal antibodies. Hybridoma 1, 257.

Tharakan, J.P., Lucus, A. and Chau, P.C. (1986) Hybridoma growth and antibody secretion in serum-supplemented and low protein serum-free media. J. Immunol. Methods 94, 225.

Warren, H.S., Glennon, M.L., Wainwright, N. Amato, S.F., Balck, K.M., Kirsch, S.J., Riveau, G.R., Whyte, R.L., Zapol, W.M. and Novitsky, T.J. (1992) Binding and neutralization of endotoxin by Limulus antilipopolysaccharide factor. Infect. Immun. 60, 2506. 